\title{
PENINGKATAN HASIL BELAJAR SISWA KELAS X MELALUI MODEL SNOWBALL THROWING PADA MATA PELAJARAN GEOGRAFI DI SMA PLUS ASSOHWAN AL-ISLAMIYAH
}

\author{
Nurin Rochayati ${ }^{1}$, Rosada $^{2}$, Ian Rozaki ${ }^{3}$ \\ ${ }^{1}$ Pendidikan Geografi, Universitas Muhammadiyah Mataram, nurin.geo99@gmail.com \\ ${ }^{2}$ Pendidikan Sejarah, Universitas Muhammadiyah Mataram, Ros ada84@yahoo.co.id
}

INFO ARTIKEL
RiwayatArtikel:
Diterima: $12-11-2017$
Disetujui: $30-12-2017$

Kata Kunci:

1. Minat,

2. Hasil Belajar,

3. Metode Pembelajaran

4. Snowball Throwing

\section{A. LATAR BELAKANG}

Dalam melaksanakan pendidikan adanya sebuah pembelajaran yang tidak dapat dipisahkan. Pembelajaran yang bermakna akan membawa siswa pada pengalaman belajar yang mengesankan. Pengalaman yang diperoleh siswa akan semakin berkesan apabila proses pembelajaran yang diperolehnya merupakan hasil dari pemahaman dan penemuannya sendiri. Dalam konteks ini siswa mengalami dan melakukannya sendiri. Proses pembelajaran yang berlangsung melibatkan siswa sepenuhnya untuk merumuskan sendiri suatu konsep. Keterlibatan guru hanya sebagai fasilitator dan moderator dalam proses pembelajaran tersebut .

Keberhasilan dari hasil belajar dengan memaksimalkan dalam pembelajaran, maka perlu dirancang proses pelaksanaan yang dapat memberikan motivasi baik bagi peserta didik maupun pendidik. Begitu juga praktek pendidikan perlu memperhitungkan kebutuhan emosional berupa rasa puas, senang dan menggembirakan. Barulah maksud dan tujuan pendidikan itu dapat tercapai dengan baik. Jika materi yang disampaikan dengan menggunakan metode atau model 
pembelajaran yang sering digunakan atau monoton, tentu membuat siswa merasa bosan dan jenuh mendengarkan guru dalam menyampaikan materi tersebut, maka siswa pun sulit menerima pelajaran yang disampaikan.

Apabila dilihat dari hasil belajar Geografi siswa di SMA PLUS ASSOHWAN AL-ISLAMIYAH, prestasi belajar mereka tergolong rendah karena 60\% siswa nilainya masih di bawah Kriteria Ketuntasan Minimal (KKM) yaitu 70. Hal ini disebabkan karena aktivitas belajar siswa masih sangat kurang, sehingga prestasi belajar yang dicapai rendah. Selain itu, seperti yang telah disebutkan sebelumnya dalam penggunaan metode pembelajaran sedikit banyak masih menggunakan metode konvensional (teacher centered) yang menjadikan siswa kurang aktif dalam proses pembelajaran. Berdasarkan hasil pengamatan awal yang dilakukan, terhadap aktivitas pembelajaran Geografi pada siswa kelas X, guru dalam hal ini belum memanfaatkan penggunaan variasi model pembelajaran. Dalam hal ini model pembelajaran snowball throwing belum digunakan guru dalam meningkatkan prestasi belajar Geografi pada siswa kelas X SMA PLUS ASSOHWAN AL-ISLAMIYAH.

Mata pelajaran Geografi adalah salah satu mata pelajaran wajib yang diajarkan kepada siswa di SMA PLUS ASSOHWAN AL-ISLAMIYAH. Geografi berperan sebagai pendorong untuk saling pengertian dan persaudaraan antar umat manusia, selain itu juga memusatkan perhatiannya pada hubungan antar manusia dan pemahaman sosial. Dengan kata lain Geografi mendorong kepekaan siswa terhadap hidup dan kehidupan sosial Hidayati, dkk., dalam jurnal kependidikan (2008). Salah satu pendekatan dalam pembelajaran Geografi dan sekaligus menjadi tugas guru pada tingkat pendidikan dasar adalah menerjemahkan materi sulit, menjadi mudah atau materi yang bersifat abstrak menjadi konkret.

Terkait dengan hal di atas, maka penulis berupaya untuk menerapkan model pembelajaran Snowball Throwing sebagai salah satu alternatif pembelajaran bermakna yang bermuara pada pembelajaran yang aktif, kreatif, efektif, dan menyenangkan

\section{B. METODE PENELITIAN}

\section{Rancangan Penelitian}

Penelitian ini merupakan penelitian tindakan kelas (classroom action research) yang dilakukan secara kolaboratif dan partisipatif. Artinya, peneliti tidak melakukan penelitian sendiri namun bekerja sama dengan guru kelas yang lain. Secara partisipasif bersama-sama dengan mitra peneliti akan melaksanakan penelitian ini langkah demi langkah Suwarsih Madya, dalam jurnal kependidikan (2006:). Penelitian ini menciptakan kolaborasi atau partisipasi antara peneliti dan guru pendamping. Peneliti terlibat langsung dalam proses penelitian sejak awal sampai dengan hasil penelitian berupa laporan.

\section{Subjek Dan Objek Penelitian}

Subjek dalam penelitian ini adalah siswa kelas X SMA PLUS ASSOHWAN AL-ISLAMIYAH yang berjumlah dua kelas yaitu kelas XA dan XB pada Semester II Tahun Pelajaran 2016/2017. Objek dalam penelitian ini adalah peningkatan hasil belajar siswa dalam pembelajaran Geografi yang difasilitasi dengan model pembelajaran snowball throwing.

\section{Lokasi dan Waktu Penelitian}

Penelitian ini dilaksanankan di SMA PLUS ASSOHWAN AL-ISLAMIYAH kelas X. Kelas X terdiri dari dua kelas yaitu kelas XA dan XB. Sedangkan pelaksanaan penelitian ini akan dilaksanakan pada bulan juni sampai bulan juli.

\section{Prosedur Penelitian}

Prosedur penelitian ini dirancang dengan menggunakan dua siklus dimana pda kegiatan siklus I antara laian: a) Tahap Perencanaan (planning); b) Pelaksaan Tindakan (acting); c) Pengamatan (Observing); d) observasi; e) Refleksi. Adapun kegiatan pada siklus II antara lain: a) Tahap perencanaan (planning); b) Pelaksanaan tindakan; c) Observasi; d) Evaluasi; e) Reflksi.

\section{Teknik Pengumpulan Data}

Pada penelitian ini proses pengumpulan datanya melalui beberapa cara yaitu dengan pedoman observasi/pengamatan, dokumentasi, tes. Apabila pengumpulan data dilakukan melalui pengamatan, maka instrumennya adalah pengamat itu sendiri, dengan alat 
bantu berupa pedoman observasi. Pengumpulan data yang dilakukan melalui pengujian, maka instrumennya adalah tes.

\section{Kriteria Keberhasilan}

Keberhasilan penelitian tindakan kelas ini ditandai dengan adanya perubahan ke arah perbaikan. Adapun keberhasilan akan tercapai apabila siswa dalam pembelajaran Geografi sudah memenuhi Kriteria Kentuntasan Minimal (KKM) yang ditetapkan. Kriteria Ketuntasan Minimal (KKM) kelas X di SMA PLUS ASSOHWAN AL-ISLAMIYAH adalah 70, maka standar ketuntasan jika 75\% dari jumlah siswa dalam kelas telah mencapai ketuntasan $\geq 70$.

\section{Teknik Analisis Data}

Dalam penelitian ini menggunakan teknik analisis data secara kuantitatif. Analisis kuantitatif dilakukan untuk mengetahui peningkatan kualitas hasil belajar dilakukan dengan cara membandingkan skor individu dan kelompok dengan tes atau nilai sebelumnya yang didapat siswa setelah mengikuti pembelajaran.

Proses analisis data dilakukan melalui beberapa tahapan, yaitu mulai dari awal pembelajaran, selama pembelajaran, sampai dengan setelah pelaksanaan pembelajaran selesai dilaksanakan. Analisis data diawali dengan mengamati data, dimana peneliti mempelajari serta memeriksa kembali secara menyeluruh data-data yang sudah dikumpulkan, baik itu data perencanaan, pelaksanaan, dan penilaian pembelajaran. Analisis data pada hasil belajar diperoleh melalui penyekoran hasil tes yang didasarkan atas kebenaran konsep. Pada setiap siklus dilakukan 1 kali tes evaluasi.

\section{HASIL DAN PEMBAHASAN}

\section{Hasil Penelitian}

Pada bagian ini peneliti menggambarkan bagaimana penerapan model pembelajaran Snowball Throwing untuk meningkatkan hasil belajar geografi siswa kelas $\mathrm{X}$ di SMA PLUS ASSOHWAN AL-ISLAMIYAH. Beberapa siklus menggambarkan tahapan penerapan metode tersebut dan dinamika pembelajaran serta implikasinya sesuai data obyektif di lapangan. Penelitian ini dilaksanakan dengan dua siklus, yang dimulai dari tanggal 22 Juni sampai dengan tanggal 22 Agustus 2016.

Hasil evaluasi siklus I dapat dianalisis bahwa dari 23 siswa yang mendapat nilai 85 satu siswa, nilai 80 sebanyak dua siswa, nilai 75 sebanyak lima siswa, nilai 70 sebanyak enam siswa, nilai 65 sebanyak empat siswa, nilai 60 sebanyak tiga orang, nilai 55 sebanyak 1 orang dan yang mendapatkan nilai 50 ada dua orang siswa. Kemudian dari analisis data diatas peneliti bisa mengkategorikan nilai yang sesuai dengan kriteria skor penilaian.

Dari data evaluasi siklus I diatas dapat dianalisis bahwa dari 23 siswa yang mendapatkan skor nilai (86100) tidak ada dengan kategori sangat baik, siswa yang mendapatkan skor nilai (71-85) delapan orang dengan kategori baik, siswa yang mendapatkan skor nilai (56-70) 13 orang dengan kategori cukup baik, sedangkan siswa yang mendapatkan skor (41-55) tiga orang dengan kategori kurang baik dan siswa yang mendapatkan skor nilai ( 0-40) tidak ada kategori sangat tidak baik.

Berdasarkan analisis data menunjukkan bahwa nilai tertinggi yang diperoleh siswa adalah 85 dengan kualifikasi baik, dan nilai yang terendah adalah 50 dengan kualifikasi kurang baik. Ketuntasan belajar siswa dapat dilihat dari hasil evaluasi siklus I berjumlah 24 orang siswa terdapat 13 orang siswa dinyatakan tuntas secara individu dan 10 orang siswa dinyatakan tidak tuntas dengan presentase 56,52\%. Ini berarti bahwa ketuntasan belajar siswa dikategorikan belum tuntas karena belum mencapai kriteria ketuntasan secara klasikal. Siswa dikatakan tuntas apabila lebih dari $80 \%$ jumlah siswa yang tuntas belajar. Dengan demikian perlu dilakukan perbaikan pada siklus berikutnya.

Hasil observasi guru pada siklus II aspek yang telah dicapai pada pengamatan ini sudah sangat baik semua aspek sudah tercapai dari ke 5 aspek tersebut, ini menunjukkan peningkatan yang signifikan jika dibandingkan dengan pertemuan-pertemuan sebelumnya pada siklus I dan II. Pada pertemuan IV merupakan pertemuan terakhir pada siklus II dan hasil yang sudah dicapaipun sudah optimal skor untuk pertemuan ini adalah $100 \%$ dengan perhitungan pencapaian disemua aspek. 
Hasil evaluasi siklus II dapat dianalisis bahwa dari 23 siswa yang mendapatkan nilai 90 sebanyak 2 siswa, nilai 85 sebanyak 11 siswa, nilai 80 sebanyak 4 siswa, nilai 75 sebanyak 3 siswa, nilai 70 tidak ada dan nilai 65 sebanyak 3 siswa. Kemudian dari analisis data diatas peneliti bisa mengkategorikan nilai yang sesuai dengan kriteria skor penilaian dapat dianalisis bahwa dari 23 siswa yang mendapatkan skor nilai (86-100) 2 orang dengan kategori sangat baik, siswa yang mendapatkan skor nilai (71-85) 18 orang dengan kategori baik, siswa yang mendapatkan skor nilai (56-70) 3 orang dengan kategori cukup baik, sedangkan siswa yang mendapatkan skor (41-55) tidak ada dengan kategori kurang baik dan siswa yang mendapatkan skor nilai ( 0-40) tidak ada kategori sangat tidak baik.

Analisis data diatas dapat dilihat bahwa nilai tertinggi mencapai 90 dengan klasifikasi sangat baik, dan nilai yang terendah adalah 65 dengan kualifikasi cukup baik. Ketuntasan belajar siswa dilihat dari hasil evaluasi siklus II di atas dari 23 orang siswa terdapat 20 orang siswa dinyatakan tuntas secara individu dan 3 orang siswa belum tuntas. Dengan demikian dapat dinyatakan presentase ketuntasan klasikal pada siklus II ini adalah 80,65\%. Ini berarti bahwa ketuntasan belajar siswa di kategorikan tuntas karena sudah mencapai kriteria ketuntasan secara klasikal. Siswa dikatakan tuntas apabila lebih dari 80\% Jumlah siswa yang tuntas belajar. Hal ini menunjukan bahwa terjadi peningkatan ketuntasan belajar yang cukup signifikan dari siklus I dan siklus II ini.

\section{Pembahasan}

Setelah berbagai data dipaparkan dan dianalisis terhadap dua siklus sudah diterapkan, maka pada bagian ini diuraikan pembahasan berkaitan dengan minat dan hasil belajar berdasarkan hasil analisis data tersebut.

a. Peningkatan minat belajar siswa

Pada aspek minat siswa, terjadi peningkatan dari siklus I ke siklus II. Pada siklus I tampak semangat, motivasi dan gairah belajar siswa relative rendah. Hal ini dapat dilihat dari kurang perhatiannya siswa terhadap materi yang diajarkan, konsentrasi siswa kurang terfokus, kerja sama siswa belum terbangun secara baik, masih adanya aktivitas siswa diluar tugas yang diberikan guru, dan sebagainya.

Dari uraian diatas memberikan gambaran bahwa tehnik pembelajaran Snowball Throwing pada mata pelajaran Geografi dapat meningkatkan hasil belajar siswa. Namun demikian kemampuan guru dalam menerapkan tehnik ini penting diperhatikan dan sangat menentukan apa yang ingin dicapai.

b. Peningkatan Hasil Belajar Siswa

Demikian juga halnya dengan hasil belajar siswa, hasil analisis menunjukan bahwa dari siklus I ke siklus II menunjukan peningkatan yang cukup berarti. Hal ini terlihat dari adanya peningkatan proses yang ditunjukan guru dan siswa, dan ketuntasan belajar siswa. Pada aspek proses pelaksanaan tehnik pembelajaran Snowball Throwing terjadi peningkatan dari siklus I ke siklus II. Hal ini Nampak dari kemampuan guru menerapkan tehnik tersebut pada siklus II, sehingga meningkatkan semangat, motivasi, kerjasama, dan prestasi siswa, jika dibandingkan dengan siklus I.

Sedangkan pada aspek hasil belajar siswa mengalami peningkatan dari siklus I ke siklus II. Pada siklus I, nilai rata-rata siswa sebesar 68,47 dengan presentase ketuntasan 56.5\%. Ini berarti ketuntasan belajar siswa belum tercapai sesuai denga ketuntasan belajar menurut standar yang telah ditetapkan yaitu $80 \%$. Hal ini disebabkan karena adanya kekurangan-kekurangan pada siklus ini. Kekurangan tersebut terutama pada proses pelaksanaan, baik yang muncul dari guru maupun siswa itu sendiri.

Namun demikian, setelah peneliti dan guru melakukan refleksi dan langkah-langkah perbaikan terhadap kekurangan pada siklus I, maka pada siklus II perolehan ketuntasan belajar siswa mengalami peningkatan dari $56.52 \%$ pada siklus I, menjadi $86,95 \%$ pada siklus II. Ini berarti ketuntasan belajar siswa telah sesuai dengan ketuntasan yang telah ditetapkan. Kondisi ini menunjukan bahwa upaya perbaikan yang dilakukan baik yang berkaitan dengan guru maupun siswa dalam pelaksanaan pembelajaran cukup tepat dan berhasil.

\section{SIMPULAN DAN SARAN}




\section{Simpulan}

Berdasarkan hasil penelitian dan pembahasan yang telah diuraikan, maka dapat disimpulkan bahwa penerapan tehnik pembelajaran Snowball Throwing pada siswa kelas X di SMA PLUS ASSOHWAN AL-ISLAMIYAH menunjukan peningkatan hasil belajar yang cukup berarti. Hal ini terlihat dari adanya peningkatan proses yang ditunjukan guru dan siswa, dan ketuntasan hasil belajar siswa. Pada aspek proses pelaksanaan tehnik pembelajaran Snowball Throwing, yang didukung oleh peningkatan kemampuan guru dalam menerapkannya berpengaruh terhadap pengembangan minat belajar siswa yang dimanifestasikan melalui perhatian, kesiapan, bakat/intelegensi, perasaan dan kerjasama dalam pembelajaran.

Sedangkan pada aspek hasil belajar siswa mengalami peningkatan yang ditandai oleh meningkatnya ketuntasan belajar siswa. Pada siklus I, nilai rata-rata siswa sebesar 68,47 dengan presentase ketuntasan $56.5 \%$. Perolehan ini dianggap belum tuntas karena belum mencapai standar ketuntasan yaitu 80\%. Kondisi ini berbeda dengan perolehan pada siklus II, dimana hasil belajar siswa mengalami peningkata dari $56.5 \%$ pada siklus I, menjadi 86,9 \% pada siklus II. Dengan demikian hasil belajar siswa dipandang sudah mencapai ketuntasan sesuai dengan standar yang sudah ditentukan (80\%).

\section{Saran}

Berdasarkan temuan dan kesimpulan yang diperoleh dalam penelitian ini, maka ada beberapa hal yang hendaknya mendapat perhatian oleh berbagai pihak yang terkait.

a. Bagi guru, sebaiknya menerapkan tehnik pembelajaran yang menekankan pada active learning, termasuk tehnik pembelajaran Snowball Throwing yang didukung dengan kemampuan guru, sehingga terbukti berhasil meningkat hasil belajar siswa pada mata pelajaran Geografi.

b. Bagi kepala sekolah, sebaiknya mengarahkan dan memotivasi para guru untuk meningkatkan kemampuan mengajar dengan menerapkan berbagai metode misalnya tehnik pembelajaran Snowball Throwing. Sehingga tujuan pendidikan akan tercapai. c. Bagi peneliti lainnya, perlu adanya penelitian lebih lanjut yang lebih luas dan beda subjek dan obyeknya.

\section{DAFTAR RUJUKAN}

Agustina. 2013. Implementasi Model Pembelajaran Snowball Throwing Untuk Meningkatkan Hasil Belajar Siswa Dalam Membuat Produk Kria Kayu Dengan Peralatan Manual. Jurnal INVOTEC, Volume IX, No.1. Bandung.

Akhiriyah. 2011. Penerapan Model Pembelajaran Snowball Throwing Untuk Meningkatkan Kualitas Pembelajaran IPS Pada Siswa Kelas V SDN Kalibanteng Kidul. Jurnal Kependidikan Dasar. Semarang.

Ardin Siallagan. 2010. Penerapan Model Pembelajaran Snowball Throwing Dalam Meningkatkan Hasil Belajar Siswa. Jurnal JUPIIS VOLUME 4 Nomor. 1. Serdang.

Arikunto. 2008. Prosedur Penelitian suatu Pendekatan Praktik. Jakarta: Rineka Cipta.

Evandari. 2012 Upaya Meningkatkan Prestasi Belajar IPS Menggunakan Model Pembelajaran Snowball Throwing Pada Siswa Kelas V di SD Negeri Ngebel Kasihan Bantul. Jurnal pendidikan. Yogyakarta.

Hamdayama. 2015. Model dan Metode Pembelajaran Kreatif dan Berkarakter. Bogor.

Irwan. 2011. Penerapan Model Pembelajaran Kumon Untuk Meningkatkan Prestasi Belajar Geografi Pokok Bahasan Cuaca dan Iklim Pada Siswa Kelas X-4 Semester Genap MA Mu'allimin NW Pancor. Jurnal Pendidikan. Selong.

Mahmud. 2011. Metode Penelitian Pendidikan. Bandung: Pustaka Setia

Pribadi. 2009. Model Desain Sistem Pembelajaran. Jakarta

Sipranata. 2013. Penerapan Metode Pembelajaran Kooperatif Snowball Throwing Untuk Meningkatkan Hasil Belajar Mata Pelajaran Perbaikan Motor Otomotif Kelas XI Teknologi Kendaraan Ringan. Jurnal pendidikan. Magelang.

Sugiyono. 2014. Metode Penelitian Kuantitatif, Kualitatif, Dan R\&D. Bandung: Alfabeta.

Utomo. 2011. Penerapan Pembelajaran Kooperatif Model Make a Match untuk Meningkatkan Hasil Belajar IPS Geografi pada Kompetensi Dasar Mendiskripsikan Kondisi Geografis dan Penduduk Siswa Kelas VII b. Jurnal Kependidikan. Malang.

Widiastuti. 2015. Efektivitas Strategi Snowball Throwing Pada Materi Keunggulan Iklim di Indonesia Kelas VIII SMP Negeri 1 Sambi. Jurnal Pendidikan. Surakarta.

Zanikhan. Minat Belajar Siswa. Dalam hhtp//www.Multiply.com/journal/item/1206/Minat Belajar_Siswa,diambil tanggal 10 januari 2016, pukul 09:17 WITA 